\title{
Social Movements, Autonomy and the State in Latin America
}

\section{Eric Sippert}

Eric Sippert, 22, is a graduate student at the University of Massachusetts Amberst pursuing a Ph.D. in Political Science. In 2014, he received his Bachelor of Arts in International Affairs at Eastern Michigan University. His interests include social movements, contentious politics, Latin America, globalization, and political theory.

\begin{abstract}
Social movements have become an important part of the political realm in Latin America, overthrowing and installing leaders as well as challenging capitalism and the state itself. This study attempts to classify social movements into four different categories by the amount of autonomy they exercise from the state and then look at the effectiveness of each of these different groups. Through examining different strategies and outcomes from social movements in Bolivia, Brazil, Ecuador and Mexico, I attempt to ascertain which degree of autonomy is most effective. This study finds that while the weakened state has made autonomous movements more effective, engaging the state can still be beneficial for social movements with achieving their objectives.
\end{abstract}

Keywords: CONAIE; Latin America; MAS; MST; Social Movements; Zapatistas 


\section{Introduction}

On January 1, 1994 in southern Mexico the Ejército Zapatista de Liberación Nacional, commonly known as the Zapatistas, rose up against the Mexican state. After twelve days the Zapatistas retreated back into the highlands and jungle regions of Chiapas. Their goal was to develop an autonomous society, "a world in which many worlds fit." The decision of the Zapatistas to not enter into electoral politics and to accept no aid from the state was seen as ludicrous by many. Although the Zapatistas initially made demands of the state, they did not wait for the state to meet them and instead began building autonomous communities themselves. Others, who were disillusioned with the electoral left as well as the guerrilla movements of the 1960s-1980s, saw it as a new path forward, a new way of doing politics. Over 2,000 miles south and eleven years later in La Paz, Bolivia, Evo Morales, the head of the Movimiento al Socialismo (Movement towards Socialism-MAS), was elected president of Bolivia. This election was not only historic because Morales was the first elected indigenous president in a country that is approximately $70 \%$ indigenous, but also because the MAS is a party constructed from a social movements base, originally primarily the coca growers' movement (Dangl, 2010: p. 13, 16-17). These two movements display opposite sides of the range of autonomy that movements may exercise. The MAS has become fully institutionalized and now even rules, while the Zapatistas have continued to exercise complete autonomy.

The recent historical context of Latin America is important to understanding the current movements of the region, and specifically the movements I will examine. Many of these movements can be traced back to the 1970s/1980s, the era of neoliberalism. Robinson describes neoliberalism as "doctrines of laissez-faire, comparative advantage, free trade and efficiency, [which] became hegemonic in universities and governments across the First World" (Robinson, 2008: p. 16). Neoliberalism in Latin America was often enforced through economic coercion as well as at the barrel of a gun. While neoliberalism began in Chile in 1973 with the US-backed overthrow of the democratically elected Salvador Allende and the free-market economic policies that Milton Friedman and other "Chicago Boys" drafted for the Pinochet dictatorship, it only reached its peak strength during the presidency of Ronald Reagan. The enforcement of neoliberal policies was often known as the Washington Consensus, which was a plan described by English economist John Williamson that included "10 policy instruments about whose proper deployment Washington can muster a reasonable degree of consensus" (Williamson, 1989). 
The ferocious form of globalization and deregulation of global capital unleashed by neoliberal economics resulted in a decrease of state participation in many spheres and a decline of state sovereignty itself. As Hardt and Negri note:

[1]n step with the processes of globalization, the sovereignty of nation-states, while still effective, has progressively declined. The primary factors of production and exchange- money, technology, people, and goods - move with increasing ease across national boundaries; hence the nation state has less and less power to regulate these flows and impose its authority over the economy. Even the most dominant nation-states should no longer be thought of as supreme and sovereign authorities, either outside or even within their own borders (2000: p. xi)

The return of electoral politics to Latin America since the 1980s has been a point of contention for many Latin Americans, who question how democratic the region actually is. Robinson argues that true participatory democracy has not been created, but rather polyarchy, "a system in which a small group actually rules, on behalf of capital, and participation in decision making by the majority is confined to choosing among competing elites in tightly controlled electoral processes" (Robinson, 2008: p. 273). These new "democratic" systems have done little to address the deep structural inequality of the region and are often run by elites who had great amounts of power before the "transition to democracy." The "transition to democracy" has aided movements by opening up space for them to express their views, but simultaneously increases the risk of cooptation and demobilization. Many who place themselves on the radical left have now abandoned the guerrilla Guevarist method of taking state power and instead seek alternative paths to accomplish radical change, focusing on transforming society from below (Webber and Carr, 2013). This study will examine how four different social movements in Latin America since the 1990s-- in Brazil, Mexico, Ecuador, and Bolivia-- exercise varying degrees of autonomy from the state, in order to determine whether exercising greater autonomy leads to greater success.

Despite the transition to democracy in the 1980s/1990s and the rise of Pink Tide governments in Latin America beginning with the Venezuelan Caracazo in 1989, Latin America is still the most unequal continent on earth (Rimsip - Latin America Center for Rural Poverty, 2011). Neoliberalism and the form of globalization it has unleashed have brought a select few into wealth, but have made an already precarious life even more precarious for many. With what can be seen as the failure of liberal democracy, many are seeking alternative methods of creating change, with social movements being one of the foremost methods. This study is important in that it questions what degree of autonomy from the state is most effective in achieving 
movement goals. It also exhibits that taking state power is not a guarantee of change. The categories of autonomy that I develop may be useful in classifying movements in other Pink Tide nation-states, as well as throughout Latin America. Further areas of research interest that could be developed from this study include movements using either the state or transnational networks as defensive mechanisms. I further suggest that social movement theorists must focus further on the internal dynamics of movements. While the leaders of vertical movements may have much to gain by cooperation with the state, the base of the movement is left without their goals met. On the other hand, horizontally organized movements may have less to gain from cooperation with the state due to the absence of a strong leader. Social justice activists from around the world must not accept the Pink Tide as inherently good, but rather be mindful of new forms of exploitation.

\section{Literature Review}

Social movements have become a driving force in politics in Latin America. The consequences of them, both intended and unintended, have been far reaching. Beginning with the period of the Washington Consensus in the 1980s/1990s, as well as the end of unfettered neoliberalism, we have witnessed a democratic opening in Latin America. This democratic opening along with the dismantling of social programs by neoliberalism has created an opening that social movements have filled and generated a protest cycle with. Some of these movements can be traced back to movements that were active during the authoritarian regimes of the 1960s/1980s while some are more recent. Along with this rise of social movements there has been an increase in left-ofcenter governments that have come to power in the region, known as the Pink Tide. I will examine the relationships between movements and the state in Latin America, especially regarding autonomy and its influence on the outcomes or success of a movement.

Much of the theoretical academic work done on social movements has unfortunately focused on movements in the developed world. Scholars such as Tilly, Giugni and Gamson have described how to classify the outcomes and consequences of social movements (Gamson, 2003: p. 350352). Hardt and Negri have provided important theoretical foundation for understanding the phenomenon of increasingly autonomous social movements by analyzing the decline of nationstate sovereignty and its effect on what they call "constituent movements," a term they use to emphasize the process of constituting collective social subjects (2000). Raúl Zibechi, focusing on Latin America, has applied and furthered the work of Hardt and Negri in his description of the space created by neoliberalism and contested by grassroots movements through new, increasingly horizontal processes of organizing. Zibechi has also produced invaluable work on 
the relationship between the new Pink Tide states and these movements (Zibechi, 2005: p. 1339). Many scholars have also worked on the current "protest cycle" in Latin America and I will draw heavily on their work regarding not only how movements operate but also why they are now occurring (Tarrow 1994).

William A. Gamson begins with the suggestion that movements do not have successes or failures but rather outcomes. These can include broad cultural and societal changes as well as policy and institutional changes. Gamson proposes that there are four possible outcomes that stem from new advantages gained by a movement and the acceptance of the movement's ideas. From these two categories movements can achieve "many" new advantages or "full" acceptance, with the opposite scenario being no new advantages and no acceptance. Obviously, there are varying degrees of these categories but for the sake of classification we will use Gamson's ideal-types. Many new advantages as well as full acceptance yields what Gamson classifies as full response. The opposite of this, no new advantages and no acceptance, yields collapse. The two other possible outcomes are co-optation, where the movement receives no new advantages but is fully accepted. The last outcome, preemption, is achieved when the movement receives no acceptance but does receive new advantages (Gamson, 2003: p. 350-352).

Marco Giugni further expands Gamson's analysis of the outcomes of social movements. Giugni usefully notes that it is imperative that scholars not only note and document the intended consequences of social movements, but the unintended consequences as well. These unintended consequences can be longer lasting and even more powerful. Giugni points out that movement outcomes can have internal or external explanations. This internal/external debate fits into the broader pluralist/elitist debate among social scientists. The pluralist side claims that political systems are responsive to social movements and therefore external pressure is effective. The counter-argument of the elitists is that political systems are essentially unresponsive and therefore movements are ineffective. However, as Giugni notes, the context of protest is also decisive. Sidney Tarrow claims that there are "protest cycles," or moments in time when movements are more likely to succeed (1994). Some have suggested that Latin America is currently in the middle of a protest cycle (Reyes, 2012: p. 1-27). The existence of this current protest cycle along with the assumption that the state acts to prolong its own existence makes external context a parameter in this study, rather than a variable. Giugni agrees with Gamson that looking at movements as simple successes or failures is not beneficial. One of the many reasons for this is that social movements are complex heterogeneous entities (Giugni, 1999: p. xiii-xxxiii). The simple success/failure binary classification assumes that movements are 
homogenous entities. Giugni further notes that outcomes are not limited to the political realm, but include cultural and societal changes as well. Lastly, Giugni recommends a four-step methodology for the study of the consequences of social movements. These tasks are 1) define the range of movement consequences, 2) specify the types of consequences to be studied, 3) search for plausible relevant causes, and 4) reconstruct causal patterns and history (Giugni, 1999: p. xiii-xxxiii).

Tilly explains the outcomes classified by Giugni's formula strength $=$ worthiness $\times$ unity $\times$ numbers $x$ commitment. If any of these numbers decrease to zero, strength falls to zero as well. Causality is also a problem in that it is difficult to prove that a movement produced the change and not an outside force. Tilly describes this as a three-circle Venn diagram in which "movement claims," "effects of movement actions," and "effects of outside events and actions" all intersect. These claims all rest on what is traditionally known as resource mobilization theory as well as the closely related political opportunity structure or political process theory (Tilly, 1999: p. 253-270).

Many scholars have noted that there are key differences between social movements in Latin America and in the industrialized Global North. However, before addressing this it is important to look at the global phenomenon of the weakening of state sovereignty, or as Hardt and Negri propose, the transfer of sovereignty from the modern nation state to "a series of national and supranational organisms united under a single logic of rule." They call this new form of sovereignty Empire. The opposite of this new form of sovereignty, or Empire, is described by Hardt and Negri as the Multitude. Instead of making demands of the traditional nation-state, groups that are within Empire but struggle against Empire must use new forms of struggle. These forces do not simply struggle against the imperial system, but struggle to create a new world as well (Hardt and Negri, 2000). I believe that many current social movements in Latin America embody this form of struggle and are examples of the Multitude that Hardt and Negri describe. George Ciccariello-Maher, as well as others also categorize these forces as constituent movements in that they are "sudden and explosive rebellions from below" in opposition to “constituted processes" or top-down (Ciccariello-Maher, 2013: 126-145).

Raúl Zibechi utilizes this constituent movement model to look at social movements in Latin America and suggests that Latin American social movements are distinct from other movements around the world. One of these historically specific characteristics is a complex mix of ideas that draws from three different currents that have shaped Latin American movements. These three main currents are liberation theology with its grassroots Christian communities, Indian insurgency with its non-Western viewpoint, and Guevarism with its potential for revolutionary 
militancy. Zibechi, like Hardt and Negri, has perceived the decline in state sovereignty and believes Latin American movements have shifted in accordance with this in order to survive. Before the 1970s, most movements were state centric and relied on what is regarded today as traditional means of organization. This organizing was generally hierarchical and a reflection of how the state is organized rather than horizontal as many movements are today. Many of these traditional movements are now struggling. Instead, there is now an increase in movements from the margins that challenge the state as well as the old Left (Zibechi, 2012). This can also be seen as a reinvention of the Lefts in Latin America (Motta, 2013: p. 5-18). Furthermore, Zibechi lays out seven trends that he believes unite the majority of Latin American movements, and some of which are unique to Latin American movements. These seven common trends are: 1) the territorialization of struggles, 2) seeking autonomy from the state, including political parties, 3) re-valorization of culture and affirmation of identity, 4) the formation of their own intellectuals, 5) inclusion of women in struggles and new gender relations, 6) a new organization of work and respect for nature, and 7) new forms of action to make the movement visible and to assert identity (Zibechi, 2012). At the same time, these so-called new movements do share similarities with movements that preceded them and many can be traced back to older movements (Becker, 2008).

The interactions between the state and social movements in Latin America, especially with the phenomenon of the Pink Tide, lead to a dynamic interplay. Movements must choose between being absorbed into institutional state structures, which in many cases claim to represent them, and fighting for constitutional change through these governments, or remaining autonomous and fighting for change as a constituent force. By looking at four different social movements that are utilizing varying degrees of autonomy, my goal is to shed some light on the advantages or disadvantages that come with working with, or through, the state apparatus.

\section{Methodology}

My research regarding social movements in Latin America can be condensed into the following question: are social movements that practice greater autonomy from the state more effective than those that are integrated into state structures? To answer this question I suggest it is necessary to categorize the various degrees of autonomy that movements can utilize. These four categories as already discussed are 1) complete integration, the movement becomes or is integrated into a political party, 2) partial integration, the movement splits into two separate groups, one of which is a political party and the other a social movement, 3) separate interaction, the movement does not enter into the state apparatus but still makes demands of the state, and 4) autonomy, the 
movement is in no way involved in the state apparatus and makes little to no demands of the state.

I will examine social movements in Latin America with my independent variable as the degree of autonomy movements utilize and with my dependent variable as these movements' outcomes/success. The work of Zibechi will help define and operationalize my independent variable (movement autonomy) while the work of Gamson, Giugni, and Tilly will help with the classification of my dependent variable (movement outcomes/success). Movement success is often a subjective measure that can be different for different members as well as different categories of members (leaders vs. base) of the movement. A heterogeneous movement has varied ideas of success. However, for this study, I will use the dominant goals of the movement as defined by manifestos, declarations, etc. as that movement's idea of success. A disadvantage of observing current movements is the time dimension. Movements may change goals and it is difficult to determine the endpoint when one can ask if the movement has succeeded. For this study, movements will be evaluated by outcomes that have already occurred. Close attention will be paid to outcomes that seem probable to materialize in the near future. The goals of movements will be studied with an emphasis on more recent goals but not forgetting past goals.

To compare these four different types of movements and examine their effectiveness I believe it is necessary to take a qualitative approach; through using the case study method, with one example of each of the four different classifications listed above using the most similar systems (MSS) method. This small-n case study method is beneficial because it allows an in-depth examination of a single movement for every category (inductive analysis); it also builds the groundwork for a larger examination in the future (deductive analysis). Through using a most similar systems analysis and choosing cases from the same time period (1980s-2010s), the historical context and the economic development of the cases becomes a constant parameter rather than a variable and therefore simplifies the examining of the dependent and independent variable. As Collier and Mahoney note, in small-N qualitative research there is a risk in overestimating the value of results of case studies (Collier and Mahoney, 1996: p. 70-71). However, by recognizing that extreme cases are presumed to be distinguishing, vital knowledge can be gained, which can be applied to other cases.

The first case study will be the Movimiento al Socialismo (MAS), Movement Toward Socialism, in Bolivia. The MAS, which can be traced back to mining and coca growers' movements, took power in 2006 through the presidency of Evo Morales (Dangl, 2010: p. 14-17). The case of MAS in Bolivia fits the first category of autonomy, complete integration, because it is a collection of 
movements that has become fully integrated into state structures and institutionalized. Although the government of Morales, like many other left Latin American states, still attempts to mobilize social movements, it is now essentially fully converted into a political party and no longer a social movement.

La Confederación de Nacionalidades Indigenas del Ecuador (CONAIE), the Confederation of Indigenous Nationalities of Ecuador, will be my second case study. CONAIE, a social movement in Ecuador, was founded in 1986. CONAIE, as the name states, is an alliance of indigenous peoples of Ecuador. After staying an extra-institutional organization for almost ten years, members of CONAIE founded the Movimiento Unidad Plurinacional Pachakutik-Nuevo País, Pachakutik Movement for Plurinational Unity-New Country, a political party commonly known simply as Pachakutik (Becker, 2008: p. 182-186). This split of a movement into a party, or partial integration, fits well into the second classification of autonomy where a social movement becomes a political party; however, CONAIE still exists as a separate entity.

The third case study will focus on the Movimento dos Trabalhadores Rurais Sem Terra (MST), Landless Rural Workers' Movement, in Brazil. This movement differs from the first two classifications and fits in the third classification of separate interaction because it has not become institutionalized or been co-opted by a political party. The MST is not completely autonomous though, because it still makes demands of the state by occupying land and then demanding legal recognition from the state (Vanden, 2012: p. 38-40).

The last case study, which demonstrates autonomy, is most likely the least common of the four classifications. The Ejército Zapatista de Liberación Nacional (EZLN), Zapatista Army of National Liberation, with their replacement of state functions of education, health, microdevelopment and justice, has come the closest to complete autonomy. Since its inception in 1994 the EZLN has attempted to exist entirely outside of the Mexican state, even refusing aid (Vergara-Camus, 2013). Therefore the EZLN is the logical choice for the fourth case study.

I hypothesize that social movements that exercise greater autonomy from the state are more effective in achieving their desired outcomes. Autonomy from state apparatuses protects movements from co-optation. It also provides new spaces for new patterns of social relation to be created as described by Zibechi (2012). Through examining these case studies with a paired comparison as described by Della Porta and using a most similar systems approach, it will be possible to prove or disprove this hypothesis (2002: p. 297). This approach is possible because of the small number of cases and the general historical traditions, geopolitical location, and 
economic development that these four states share. Through examining the stated goals of movements through manifestos, declarations, and other documentary evidence and then examining the outcomes caused by these movements, it is possible to test the hypothesis.

\section{The MAS in Bolivia}

The first case study of the MAS in Bolivia is unique because it is now wholly a political party even though it attempts to mobilize and use social movements to legitimize itself and maintain power. Although not exclusively an indigenous party, the MAS is the first majority indigenous party in Latin America to be elected into power (Van Cott, 2005). I will first outline a brief history of the MAS from its inception as the coca growers' movement in the 1980s to its transition into a political party. Then by looking at the stated goals of the MAS, primarily voiced through President Evo Morales and his administration, it is possible to observe the outcomes for the MAS and to discern how harmonious they are with their stated goals.

In December 2005, Evo Morales was elected president of Bolivia. An Aymara indigenous man, Morales' victory was historic for a nation-state that is 70\% indigenous but has never had an indigenous president. Not only is Morales the first indigenous president, but he has also been labeled as a "social movement president" because much of his power is drawn from social movements and his party, the Movimiento al Socialismo (Movement towards Socialism-MAS), is made up from a collection of social movements ((Morales, 2012: p. 49).

The birth of the MAS can be traced to the coca growers' movements, which grew as a response to the 1980s neoliberal shock policies proposed by the US and the IMF, as well as the US-led socalled war on drugs. The shock therapy prescribed by the US ended Bolivian government subsidies and privatized much of the Bolivian economy, leading to economic as well as social upheaval. The war on drugs in Bolivia, where the coca leaf is grown as a traditional mild stimulant by many indigenous groups, threatened many coca growers' way of life. The union created by the coca growers' movement played an important role in the Cochabamba Water War of 2000 and the Gas War of 2003. The Cochabamba Water War was caused by a plan to privatize water by the multinational corporation Bechtel, while the Gas War was initially in response to a plan to export natural gas through Chile with little of the revenues going to the Bolivian people. These two events served to mobilize and unite Bolivian social movements and civil society and paved the way for the election of Evo Morales. These mobilizations were spontaneous in that they were in response to two specific problems, but they showed an organization of Bolivian society. Coca growers played an important role in the Water War; and 
then in the Gas War neighborhood councils (FEJUVEs), which were often made up of unionized miners, led many of the demonstrations. The heavy repression of the state against these protests led to further unity among protesters, even across class lines (Dangl, 2010: p. 1618). When Morales became president, he inherited a repressive state apparatus, still present from the military rule of 1964 to 1982 , that would not be easy to reform.

Webber and Dangl have described the goals of the MAS as anti-capitalist, communitarian socialist, and indigenous liberationist (Webber, 2010). Morales has also spoken extensively on the importance of decolonizing the state; however, in their now nine years in power the MAS government has done little to achieve these broad goals and have instead focused on short term reform-oriented issues (Webber, 2013: p. 152). Four central compact goals of the Morales-MAS government are the nationalization of hydrocarbons (oil and gas), redrafting the constitution through a Constitutional Assembly, indigenous liberation through more rights and power, and a referendum addressing the issue of autonomy (Morales, 2012: p. 60). The following section will examine the degree to which each of these goals has been achieved.

Scholars have debated how to characterize the political economy of Bolivia since the election of Morales. Jeffery Webber has designated the political economy of the Morales regime as a reconstitution of neoliberalism, while Federico Fuentes has stated that Morales and the MAS represent dramatic change. Even though Fuentes correctly exhibits a number of gains by the Morales regime, Webber makes a couple of key rejoinders. First, that the process of neostructuralism sweeping Bolivia is not a break with neoliberalism, but simply an adaptation. Secondly, much of what Fuentes calls the success of the Morales regime has been due to what Webber describes as "a critical left-collection of thinkers" and movements, i.e., concessions forced on the Morales government (Fuentes, 2010). The MAS originally formed itself in opposition to the results of neoliberalism, so to then reconstitute neoliberalism would be a fundamental betrayal of the MAS's original goals. While many saw the MAS as a revolutionary socialist movement, once elected the vice-president García Linera (a former Marxist intellectual) quickly proclaimed that socialism would not be attainable for at least fifty to one hundred years, and that instead Bolivians should follow an "Andean-Amazonian" capitalist model.

The MAS would also focus heavily on indigenous liberation, which the MAS views as separate from economic transformations. This has been a source of contention among indigenous groups, who posit that indigenous liberation is not possible without the ability of indigenous peoples to make their own economic decisions. The Morales regime has been accused of using the rhetoric of indigenous liberation as an election promise that he cannot keep, a problem that 
non-party social movements do not face (Webber, 2013: p. 169-170). One of the first and most consistently stated goals of the MAS is the nationalization of hydrocarbons. The MAS and supporters of the MAS have claimed that this has happened, but not nearly to the extent that the term nationalization implies. Instead of truly nationalizing the hydrocarbon industry, the MASMorales government has cooperated with Indian, Korean, Japanese, Canadian, U.S. and Swiss multinational corporations. To this day multinational corporations own the majority of active mines in Bolivia. The two large exceptions touted by the MAS, the Huanuni mine and Vinto smelter, are results of struggles from below that forced the MAS-Morales government into action. Webber describes the so-called nationalization well: "the presidential decree... did not result in the actual nationalization of the industry but rather signaled a moderate reform to the regime of royalties and taxes owed to the Bolivian state by multinational oil and gas companies" (Webber, 2013: p. 178-179). This has led to an increase in the amount of revenue received by the state because it coincided with an increase in the price of natural gas, i.e., a continued dependence on global market forces and foreign investors. This model has been described as neo-extractivism because while a large scale of revenues goes to social spending it is still topdown, paternalistic, and leaves the country dependent on foreign capital and markets. Governments like the Morales and Correa regimes in Bolivia and Ecuador support this developmental model as a way to increase funding for social programs, but others have noted that it demobilizes grassroots movements.

In addition to failing to nationalize hydrocarbons, the quality of life for most Bolivians has not improved under the governance of the MAS-Morales government. Social spending and fiscal stimulus have been especially low for a party claiming to oppose neoliberalism. Fuentes and Pablo Stefanoni have compared the Morales regime to the progressive time period after the 1952 Bolivian revolution, but total state involvement in the economy is currently only at $32 \%$ of GDP, while it was $52 \%$ in 1952 by conservative estimates. State employment in the 1960s was at higher levels than it is currently. Income inequality has been slightly lowered, with the Gini coefficient changing from 60.2 to 56.3 between 2005 and 2007. Inequality still reigns in the one of the most unequal countries in the most unequal region of the world. This illustrates that there has been no revolutionary change in the political economy of Bolivia as well as an absence of significant structural reforms (Webber, 2013: p. 176-178).

The goal of re-founding and decolonizing the state through the drafting of a new constitution has resulted in mixed outcomes. The Constituent Assembly was dominated by indigenous and peasant organizations but still faced considerable hurdles. These hurdles stemmed from ethnic, 
class and regional tensions. This can be seen as an effect of the state, which seeks to co-opt, demobilize, and divide constituent forces in an attempt to control them. After many setbacks the new constitution was approved in 2009 with $61 \%$ of the vote. Immediately after the ratification of the new constitution, three departments rejected it and violence broke out across the country (Morales, 2012: p. 67). Many of these tensions are due to the issue of autonomy of the departments of Bolivia; not autonomy from the state apparatus, but instead the desire of the white business elites who control these departments to maintain their privileged status through local control of the valuable hydrocarbon resources concentrated there.

As W. Morales notes, the issue of secession has always been a problem for Bolivia due to its history of being created as a buffer state. Recently, the eastern departments, known as the media luna, have been at the forefront in calling for secession. These departments are more prosperous and conservative than the rest of the country, as well as largely non-indigenous. The media luna has presented a huge problem for the Morales regime and both the ratification of the new constitution and Morales' reelection have done little to solve the issue (Morales, 2012: p. 61, 6365). The dissenting voices of the media luna region also give the Morales regime an excuse to dismiss grassroots forces as counterrevolutionary and to repress them, including the very coca growers that brought Morales to power (Oikonomakis, 2014). Left grassroots forces in Bolivia must balance criticizing and pushing the Morales regime without inadvertently strengthening the traditional right wing elite in the media luna.

The MAS and Morales were elected in 2005 with lofty rhetoric of a radically different future. Since taking power the MAS has had little success in achieving the goals it had set out for itself. The living standards of the vast majority of Bolivians have remained unchanged, and the socioeconomic framework that created the vast inequality remains with few structural changes. Bolivians are still confronting the challenges faced under neoliberalism despite a social movement party being in power. Instead of ending neoliberalism in Bolivia, the MAS have reconstituted it. This can be seen through the failure of the MAS to fully nationalize the hydrocarbon industry. The few changes that have occurred in Bolivia can be attributed to constituent social movement forces from below rather than constituted processes. One of the lone exceptions to this is the ratification of the new constitution, which creates some space for grassroots groups to continue to mobilize as an outside pressure on the state. The MAS also must deal with secessionist forces in the eastern departments that are attempting to tear apart the country, and that wield considerable local electoral clout. Through the case study of Bolivia and 
the MAS we can see that change is not guaranteed when a social movement becomes a party, even if they are elected into power.

\section{CONAIE and Pachakutik in Ecuador}

Ecuador has had one of the most tumultuous recent histories of Latin American states. Heads of state have come and gone, but little fundamental change has occurred. The recent election of Rafael Correa in 2006 and re-election in 2009 provided hope for leftists, indigenous groups and marginalized populations. The largest indigenous organization in Ecuador, La Confederación de Nacionalidades Indigenas del Ecuador (Confederation of Indigenous Nationalities of EcuadorCONAIE), is one of the most vocal opponents of the Correa administration after initially supporting him in the run-off election in 2006. CONAIE is a social movement that has attempted to enter the realm of institutionalized politics through the creation of a political party, while also maintaining an extra-institutional movement. The outcomes of their foray into electoral politics provide a valuable lesson for social movements throughout the region.

CONAIE was founded in 1986 as a collection of three indigenous organizations, the Confederacion de Nacionalidades Indígenas de la Amazonía Ecuatoriana (Confederation of Indigenous Nationalities of the Ecuadorian Amazon-CONFENIAE), Confederación de Pueblos de la Nacionalidad Kichwa del Ecuador (Confederation of Peoples of Quichua Nationality- ECUARUNARI), and Coordinadora de Organizaciones Indigenas y Negras de la Costa Ecuatoriana (Coordination of Indigenous and Black Organizations of the Ecuadorian Coast-CONAICE), that had come to the realization that the indigenous peoples of Ecuador were not represented in Ecuadorian electoral politics and needed another method to press their goals. CONAIE was a precursor of many "new" Latin American social movements with its horizontal, participatory democratic and inclusionary style of organizing (Dangl, 2010: p. 44). Becker has noted the distinctive nature of the CONAIE organization, specifically through their use of nationality, or nationalities, as a tool of organization. This idea of indigenous nationalism is a product of years of interaction between leftist and indigenous forces in Ecuador and through the upper Andes. Becker further argues that much of the success of CONAIE can be attributed to their combined use of class, ethnicity and nationalism together, instead of as separate identities as many leftist and indigenous groups attempt in their organizational strategies (Becker, 2008: p. 71).

In 1995, after years of discussion CONAIE formed the Movimiento Unidad Plurinacional Pachakutik - Nuevo País (Pachakutik Movement for Plurinational Unity - New Country, MUPP-NP) as a political party to participate in electoral politics. Pachakutik is an Andean term that comes from 
the Inca and is defined as a time of reawakening or the "awakening of a sleeping giant" (Becker, 2008: p. 176). CONAIE originally used the term to describe the 1990 indigenous levantamiento (uprising), which consisted of traffic blockades and occupations aimed at pressuring the government to fulfill CONAIE's demands of bilingual education, land reform, and a new constitution. I will use the term as the political party, MUPP-NP. The creation of Pachakutik symbolized a deep change in CONAIE policy. In 1990, at the third congress of CONAIE, it was agreed "not to participate in elections because neither the political system nor political parties were functioning in a way that represented people's interests" (Becker, 2008: p. 184). This shift was partially due to an increase in foreign investment in hydrocarbons, and a perception that para-parliamentary efforts were insufficient. The participation of Pachakutik in electoral politics has yielded mixed results. In 2002, Pachakutik and CONAIE backed the campaign of Lucio Gutiérrez, military leader of a reformist coup two years earlier. While CONAIE and Pachakutik's support of Gutiérrez helped lead to his victory and resulted in Pachakutik politicians being appointed a number of government positions, immediately after being elected, Gutiérrez signed an agreement with the IMF and turned his back on the very people that brought him to power. CONAIE and Pachakutik broke ties almost immediately with the administration, but the damage had already been done (Dangl, 2010: p. 46-47).

The relationship of Correa with CONAIE and Pachakutik has been contentious from the very start. When Correa first ran in 2006, CONAIE and Pachakutik, wary from the fiasco of 2002 decided to run their own candidate in opposition to him. After a resounding defeat for the Pachakutik candidate in the first round, Pachakutik and CONAIE threw their support behind Correa for the run-off election against the right-wing candidate, wealthy businessman Álvaro Noboa. After Correa's election and his efforts to silence indigenous opposition, expand privatization, and utilize neo-extractive policies CONAIE and Pachakutik completely boycotted elections in 2009 (Dangl, 2010: p. 49-53). The decision not to participate can be viewed as a partial withdrawal of CONAIE and Pachakutik from electoral politics, although Pachakutik does continue to and indeed has more success in participating in local elections (Becker, 2012: p. 128).

The broad goals of CONAIE at its creation focused primarily on land, economic development, education, and recognition of indigenous nationalities. They expanded to include the concrete goals of bilingual education, recognition of traditional medicine, the reestablishment of relations with the Sandinista government in Nicaragua, agrarian reform, and a new pluri-national constitution (Becker, 2008: p. 166). As already described, CONAIE initially saw a grassroots broad extra-institutional movement as the best way to achieve their goals; however, after almost 
ten years of struggle the decision was made to enter electoral politics. In relation to this study, the question is then, has the splitting of and entering of CONAIE into the world of electoral politics, through Pachakutik, increased their success in attaining their goals?

One of CONAIE and Pachakutik's goals, as well as many movements from all around Latin America, is land and agrarian reform. During the uprisings of the early 1990s thousands of CONAIE members marched on Quito to demand land reform. They were awarded titles to only half of the land they asked for and "the state continued to legally own and control the subsoil, and... any activity that blocked oil operations would be deemed illegal" (Dangl, 2010: p. 45). This is emblematic of the struggle between CONAIE and the state for land; small victories will take place that can easily be pushed back, but little permanent change happens. This has only continued under the Correa administration. In 2007 indigenous protestors attempted to set up roadblocks to prevent access to oilfields. Correa responded by declaring a state of emergency and brutally repressing protestors (Dangl, 2010: p. 54). This is one example of many of clashes between the Correa administration and CONAIE due to Correa's extractive development policies.

While Pink Tide regimes such as Correa's in Ecuador point to the partial nationalization of industry as a sign of their progressiveness, critics have pointed out that neoextractivism, the extraction of raw natural resources for export with nominal nationalization, is a surface deep reform that has not changed any of the structures of exploitation. As Acosta states,

"As in the past, the lion's share of the benefits of this economic orientation goes to the rich countries, the importers of Nature, which profit still further by processing and selling it in the form of finished products. Meanwhile, the countries that export primary commodities only receive a tiny percentage of the revenue from mining or oil, but they are the ones who have to bear the burden of the environmental and social costs” (2011: p. 74).

The neoextractive development policies of Correa have therefore led to continued clashes between social movements such as CONAIE and the government because of their inability to change the economic inequalities that led to the creation of the movements.

Another large goal of CONAIE and Pachakutik was the redrafting of the state constitution into a constitution that declared Ecuador to be a pluri-national state, gave more rights to indigenous nationalities, and also protected the rights of nature. This was accomplished by the Correa administration in 2008 and was passed by $64 \%$ of voters in 2008. The passing of the new constitution can certainly be attributed to constituent movement pressure from below, especially 
from CONAIE. The new constitution was not without problems though. The constituent assembly, which drafted the constitution, faced harsh criticism for being composed almost entirely of party members rather than members of movements (Dangl 2010, p. 49-53). In spite of this, the new constitution is more progressive and does recognize Ecuador as a pluri-national state. This has not stopped Correa from passing laws that harm the indigenous people of Ecuador as well as attempting to co-opt and divide them. Examples of this include the closing down of the Development Council of the Indigenous Nationalities and Peoples of Ecuador (CODENPE), placing the National Directorate of Intercultural Bilingual Education (DINEIB) under state control, and attempting to divide and conquer by backing moderate social movements such as the Ecuadorian Federation of Indians (FEI) over more radical movements like CONAIE (Becker, 2013b: p. 50).

CONAIE and Pachakutik have changed the political landscape of Ecuador through their actions. Although Ecuador still faces a highly unequal land system with many problems, the passing of a new constitution and the labeling of Ecuador as a pluri-national state offers hope for permanent change. The entrance of CONAIE into electoral politics was initially disastrous and is still ineffectual at a national level, but CONAIE has made gains at a local level. As Becker notes, "[i]ndigenous movements in Ecuador... no longer see electoral and extra-constitutional paths to power as mutually exclusive" (Becker, 2013a: p. 229).

\section{The Brazilian MST}

The recent economic rise of Brazil has attracted international attention and has been accompanied by increased social spending, which has lifted certain segments of society out of poverty. This has not included all however. Historically, one of the most marginalized groups in Brazil has been the landless. Since the creation of the Movimento dos Trabalhadores Rurais Sem Terra (Landless Rural Workers Movement - MST) in the 1980s, they have struggled for primarily land as well as other rights. This illustrates the third category of autonomy to be observed, separate interaction. The MST is a social movement that has not entered into electoral politics or been coopted by a political party despite making demands of the state through land occupation, and sometimes entering into strategic alliances with the Partido dos Trabalhadores (Workers' Party PT).

The MST began in 1984 in southern Brazil. One of the factors leading to the creation of the MST was Brazil's unions' refusal to allow landless famers into their ranks. This dissatisfaction and exclusion from traditional union methods of land struggle led to the rise of the MST. The 
MST also differs from unions through its acceptance of all members of the family as movement members, including children. The primary tactic of the MST has always been the occupation of land. Once the land has been occupied the MST calls on the government to grant them a land title by citing the 1988 constitution, which states that all land must be used for the good of society. The National Colonization and Agrarian Reform Institute (INCRA) must then pay the landowner for the land and appropriate it, and then give the title to the MST members. This mix of autonomy and pressure on the government has made the MST the largest social movement in Latin America and one of the most successful. This is due to not only the MST's success in building links between urban and rural sectors, but also the fluidity provided to them by not being a political party. This fluidity allows the MST to quickly make alliances with other movements and participate in other struggles, such as the recent public transit fare protests (Zibechi, 2012). This appeals to many, even those who are not rural landless, such as the youth in Brazil who are "fed up with this bourgeois way of doing politics" (Vlana, 2013). As Dangl notes, "[the] MST"s actions are organized around building democratic, self-managed communities, while simultaneously pressuring the government to grant legal reforms" (Dangl, 2010: p. 123).

Although MST members must often wait between two to four years for land titles to be awarded, this does not stop them from using the land. After occupying the land with large groups of members, male, female, and children, the MST immediately begins cultivating the land as well as setting up schools, health and social services (as reflected in their motto, "Occupy, Produce, Resist"). The use of these direct action tactics makes the MST sustainable and they make it much more difficult for the state to simply evict the occupiers (Wright and Wolford, 2003). Ben Dangl has attributed the growth and what he calls the success of the MST to the structure of the organization. In contrast to many organizations that make demands of the state, such as the unions the MST broke away from, as well as the state itself, the MST is organized in a more horizontal manner. The horizontalism of the MST is an example of a new way of organizing political and societal entities; greatly different from a state-centered hierarchical approach. Members belong to grassroots groups that are participatory and attempt to reach consensus rather than a simple majority. This decentralized structure increases the mobilization potential of the MST. The participatory model of decision-making also increases the legitimacy of the movement with its members and the sustainability of the movement over a long period of time (Dangl, 2010: p. 123-125). This increase in sustainability is due not only to the fact that there is no "strong man" leader, but also to the horizontal bonds fostered and strengthened by 
the mistica, the emotional/subjective sense of collectivity of the movement, fostered through symbolic group exercises and activities.

Initially, the goals of the MST focused exclusively on land reform; through the acquiring of land through occupation. Gradually this expanded into creating autonomous schools and health clinics in the occupied settlements. These schools and clinics filled a gap in people's needs that the state had not provided for. Simultaneously to establishing schools and clinics, the MST also participates in marches, blockades, and occupations that demand better education and healthcare from the state. Another point of contention for the MST is the growth of industrial farming and the use of genetically modified organisms (GMOs). The combination of these two practices has threatened MST members' way of life, even if they receive the land they struggled for. Although not all MST members practice organic farming, many have embraced it as an alternative to the industrial farming model (Dangl, 2010: p. 122 and Vanden, 2012: p. 34-48).

As the MST gained strength in the 1980s, another older movement, the Workers Party (PT), which came from union organizing and the movement for democratization after two decades of military rule, grew and eventually entered electoral politics. The last two presidents of Brazil have come from the PT. The PT has faced harsh criticism for their rightward turn and move from being a "workers' party" after entering office; however, they were elected with the help of more radical movements such as the MST. This rightward turn (leaving the PT now in the center of the political spectrum) can be viewed from an international perspective, as an appeasement to global capital and hegemonic powers, evident through the strengthening of bonds with transnational finance and agri-business (Motta 2013a). From a domestic perspective, this rightward turn dampened discontent from the Brazilian right and strengthened the MST's mandate to rule from business and landowning elites. The MST helped Lula win the presidency in 2002, but then declined to take part in the government structure, thus avoiding the cooptation that has taken place in Ecuador with CONAIE and Pachakutik in Ecuador (Vanden, 2012: p. 43-45). The MST not only makes demands of the state, but also throws its support behind political parties when necessary and then withdraws once elections have occurred. This allows the MST to help prevent the election of right wing parties that directly oppose the MST's interests. At the same time, while insuring that the more progressive of the available parties is elected, the MST keeps their distance from the party and utilizes their constituent power to influence and push the left-leaning party in power. Interestingly, members of the MST have entered into electoral politics on the PT ticket, due to the MST's policy not to run their own candidates. Members of the movement must agree upon this before an individual enters an 
election. The MST and PT generally have had close relations on a small local level, which decrease dramatically as one goes further up the state hierarchy (Vanden, 2007: p.54). However, the MST has moved even further from the PT after what many see as the betrayal by Lula (Vergara-Camus, 2009: p. 187). The MST must face the question whether supporting the PT is worthwhile at all.

This policy of separate interaction has led the MST to be one of the most successful social movements in Latin America today. The autonomy that the MST exercises from the state allows them to create a unique culture and identity in their occupied settlements without it being subsumed by the state apparatus. Some of the outcomes achieved by the MST include the expropriation of 35 million acres of land that is now inhabited by almost 400,000 families, one natural medicine factory, 1,600 government recognized settlements, health clinics, 1,800 schools for over 160,000 students, an adult literacy program with 30,000 students, and a university. On top of this there are still 100,000 families waiting for land titles from the state. (Dangl, 2010: p. 121, 136).

An area where the MST has been less successful is in their struggle against industrial farming and GMOs, which raises the question, is the movement actually effective when it expropriates land through the state but then is unable to survive on that land due to outside market forces? Zibechi notes that, "The development and control of new technologies by multinationals has made possible a new type of oppression... the multinationals' dominance is of an 'immaterial' sort, resting upon control over knowledge and the market in order to maximize profit accumulation" (Zibechi, 2012: p. 125). The MST is in a conundrum. They use the state as a tool to achieve their goals and as a defensive tool to protect their gains, but as Hardt and Negri have pointed out, the sovereignty of the state is dissipating. The MST face the constant problem of the state co-optation as well as the state's weakening power to protect the gains the MST has made in the face of increasing global capital or Empire.

\section{Mexico and the Zapatistas}

The Ejército Zapatista de Liberación Nacional (Zapatista Army of National Liberation - Zapatistas) are perhaps the most well known of Latin American social movements. Their high degree of autonomy from the Mexican state distinguishes them from the vast majority of social movements. This autonomy exercised by the Zapatistas fits them well into my fourth category of autonomy from the state, autonomy, in which a movement makes no demands of the state apparatus. The Zapatistas exercise autonomy not only politically through not entering the realm 
of electoral politics, but also territorially by creating autonomous communities and municipal councils administered by regional Juntas de Buen Gobierno (councils of good government), whose members are chosen by participatory assemblies of the communities themselves.

The Zapatistas rose up in 1994 in the southern Mexican state of Chiapas. Initially, in the First Declaration of the Lacandon Jungle, the Zapatistas declared war on the Mexican state and called for the people of Mexico to march on Mexico City and seize power (EZLN, 1994). After only twelve days of armed struggle against the state the Zapatistas retreated into rural Chiapas to build their autonomous communities. There they have functioned as more of a social movement than as an armed rebellion. For the last twenty years the Zapatistas have been working on transforming society through a "glocal" approach; concretely living and creating new social relations in a local setting, while utilizing global interest and shared agendas and "frames" of the alterglobalization transnational social movements as a defensive protection and as a tool in their struggle (Stahler-Sholk, 2010: p. 269-271).

The Zapatistas have outlined their goals in manifestos known as declarations from Lacandon jungle. There have been five additional declarations since the initial one for the uprising in 1994. These declarations allow us to trace the trajectory of the Zapatista movement and their shifting goals. The first declaration declares war on the Mexican state and calls on forces to "Advance to the capital of the country, overcoming the Mexican federal army, protecting in our advance the civilian population and permitting the people in the liberated area the right to freely and democratically elect their own administrative authorities" (EZLN, 1994a). The second declaration, issued in June of 1994, reflects what was at that time the recently declared ceasefire between the Zapatistas and the Mexican state. It urges the protection of civilians as well as the following of ceasefire agreements from all sides, agreements which the Mexican government promptly proceeded to violate with a February 1995 military offensive (EZLN, 1994b). Two years after the initial uprising the Zapatistas released their fourth declaration. This declaration outlined the goals of "Housing, land, employment, food, education, independence, democracy, liberty, justice and peace." It then reaffirms the EZLN as a non-state oriented political force, but instead a peaceful civic social movement struggling not only against the Mexican state but neoliberal globalization as a whole (EZLN, 1996). The fifth declaration, released in 1998, focuses on the rights of the indigenous of Mexico as well as the need for different indigenous groups to unite and work together (EZLN, 1998). The most recent, Sixth Declaration of the Lacandon Jungle reaffirms the history of the Zapatistas, explains how they see the world and Mexico, and then calls for the beginning of the Other Campaign. This campaign calls for a wide variety of 
anti-capitalist alterglobalization groups to work together. The declaration focuses on the need for a worldwide struggle rather than simply a Mexican struggle (EZLN, 2005). The timing of Other Campaign, coinciding with the 2006 presidential election (which produced the dubious victory of Felipe Calderón and policies that reinforced many Mexicans' skepticism about their political system) can be seen as a way for the Zapatistas to shift public attention away from the six-year Mexican electoral cycle. In terms of the immediate goal of solidifying social movement alliances, the Other Campaign had limited success, because of heavy Mexican state repression against groups that declared themselves "adherents" to the Sixth Declaration of the Lacandon Jungle (Mora, 2007: p. 64-77). The Zapatistas essentially closed themselves off from the outside world after the Other Campaign, focusing inward on consolidating their autonomy project until 2013 with the creation of Escuelitas, an initiative in which outsiders were invited into their communities to learn first-hand about the movement.

The struggle of the Zapatistas is distinctive in that they are not pressuring the state to give them their goals, but struggling to create them themselves. Therefore it is possible to view the struggle for real autonomy by the Zapatistas as one of their most pressing goals, or needs. As StahlerSholk has noted, the desire for autonomy by the Zapatistas has not come without potential problems, including the risk of being shut out from the rest of the world and the availability of resources (Stahler-Sholk, 2007: p. 48-63). The Zapatistas have dealt with this by creating their own government structures including councils of good government and caracoles (regional centers of autonomous government). In addition, the Zapatistas have attempted to create economic autonomy, which includes only allowing certain NGO sponsored projects (Barmeyer, 2009). This allows the Zapatistas to guide their own development, rather than it being developed from the outside. Harvey argues that the autonomy claimed by the Zapatistas is "the Zapatistas' most significant political achievement," and that the Zapatistas are moving not only outward, through working with international groups, but also inward through their development of autonomy (Harvey, 2005: p. 15). The Caracoles are the quintessential example of this. They follow the motto of mandar obedeciendo ("lead by obeying") and act as regional clusters of autonomous municipalities that are led by the communities themselves, while still interconnected with one another (González Casanova, 2005: p. 79-81).

Zibechi has pointed out that this autonomy has led to a "significant improvement in the quality of life" for those living in Zapatista communities through the self-management of education, healthcare, and agricultural practices (Zibechi, 2012: p. 129). This is an example of success of the goals of housing, land, employment, food, and education facilitated by the Zapatistas' direct 
action in occupying or "recovering" private lands, and farming some of them collectively in order to generate resources for autonomous social programs. Quantitative measures of success include two hospitals, eighteen clinics, 800 community health centers, and over 500 health promoters, as well as three hundred schools, 1,000 education promoters and a center for secondary education (Zibechi, 2012: p. 132). In an impoverished region like Chiapas, educational and health related advances have often taken priority over economic and political ones. This has not stopped economic advances, which must focus first on breaking out of the neoliberal system. This has been done through cooperatives, fair trade enterprises, and de facto agrarian reform in which the Zapatistas have "recovered" or occupied private lands.

The choice of the Zapatistas to pursue a path of complete autonomy from the state is fraught with challenges and dilemmas. While offering many advantages that movements that deal with the state apparatus do not have, this strategy presents other problems. The autonomy of the Zapatistas from the state has not prevented the state from challenging the Zapatistas. Since 1994 the Zapatistas have had to deal with the constant presence of the Mexican military and the lowintensity warfare that the state is waging. In more recent years the Mexican state has attempted to use co-optation and clientelism to usurp the Zapatistas through giving aid to non-Zapatista peasants and encouraging the "development" of Chiapas by so-called ecotourism and other projects of large-scale capital. Meanwhile, the Zapatistas face the constant question of how much they should open themselves to the outside world in their attempt to create a new one.

\section{Results and Conclusions}

The vehemence with which neoliberal globalization was forced on Latin America, started in the late 1970s, changed the political structure of the region immeasurably. The retreat of the state from social and civic spheres created an opening that a new type of social movements filled, but those movements also had to contend with the newly freed forces of global (and mobile) capital. Many of these movements still insisted on organizing themselves in a hierarchical manner as the state does, while others adopted a more horizontal organization, sometimes linking with homologous groups in transnational networks. Some have entered into electoral politics or been co-opted by parties while others have not. As state sovereignty continually shifts, and is assailed by global capital, movements must make difficult decisions with respect to how much autonomy to exercise from the state and what demands to make of the state. Categorizing movements by the degree of autonomy they exercise from the state as 1) complete integration, 2) partial integration, 3) separate interaction, or 4) autonomy provides a useful means of classifying movements, but the question of measuring success still remains. 
One of the most significant barriers to measuring outcomes of the four movements studied here is that they are all still ongoing and therefore it is impossible to draw definitive conclusions. A second barrier is the specificity of Latin American social movements. While many movements in the industrialized North seek reformist goals that simply seek to change policy, such as mainstream environmental and gay rights groups, many Latin American movements challenge the state itself and seek a broad transformation of society. This is perhaps a consequence of the history of the continent as a testing ground for colonialism, neo-colonialism, neoliberalism, and now unfettered global capital. Through examining movement outcomes and comparing them to stated goals of movements, it is possible to gauge what has been accomplished. Table 1, "Stated Goals vis-à-vis Outcomes," provides a concise summary of stated goals and outcomes. The degree of success is then ranked as "low," "medium," or "high" depending on how closely the outcomes of each movement match the stated goals. From there I will examine my initial hypothesis.

My initial hypothesis was that the greater autonomy that a movement exercises from the state, the more effective they will be in achieving their goals. After examining these four cases I now find this to not be entirely correct, though Table 1 does seem to show a general correlation. Hardt and Negri correctly point out that there is a transfer of state sovereignty, often to international organizations and networks, however the state is not dead. This is illustrated negatively by the low-intensity warfare and outright state repression faced by movements, for example the Zapatistas in Mexico. While movements may withdraw from the state apparatus, the state still attempts to control movements through co-optation, low intensity warfare, or direct conflict. This state response is an additional variable that must be factored in. Global capital and imperialism also can have a devastating effect on movements. Movements in Latin America must face the double-edged sword of global capital, capital that is tearing apart the state and creating spaces for movements but also weakening the ability of movements to fight global capital through the state. William Robinson claims that the state is still crucial and that "[a] confrontation with the global capitalist system beyond the nation-state, moreover, requires national state power" (Robinson, 2008: p. 344). Social movements are still grappling with effective strategies for confronting these dilemmas.

State institutions have been used as a defensive measure by movements such as the MST in Brazil, in that the movement pressures these institutions to issue land titles and provide legal justification and proof of MST members' right to the land. The success of the MST is remarkable; the expropriation of 35 million acres of land that is now inhabited by almost 400,000 
families, one natural medicine factory, 1,600 government recognized settlements, health clinics, 1,800 schools for over 160,000 students, an adult literacy program with 30,000 students, and a university. On top of this there are still 100,000 families waiting for land titles from the state. (Dangl, 2010: p. 121, 136). The MST has had a contentious relationship with the PT, but their separation from electoral politics is not total. Through actively participating in Brazilian elections the MST helps insure that rightwing forces do not gain power. For all of the criticism that the PT has faced from within and outside of Brazil, including from the MST, the MST realizes that they are far preferable (in terms of the movement's goals) to a rightwing ruling party or a return to the dictatorships of the 1960s to 1980 s.

Out of these four movements I suggest that the MAS in Bolivia has been the least successful. The decision to enter electoral politics, while seeming to be hugely successful at first, has exposed the MAS to a multitude of challenges and pressures, from secessionist groups in eastern Bolivia to US neo-imperialist forces. Even with the passing of a new constitution, the Morales regime has been unable to create deep structural change and has instead focused on shallow reforms. Moreover, by entering electoral politics, the MAS has alienated many of the movements that brought it to power. Given this isolation from part of its movement base the MAS is vulnerable to pressure from all sides, including the rightwing secessionist forces, the U.S. government, social movements that once supported it, and global capital. Its path in the near future will affect the social movements of Bolivia greatly.

Much like the MAS in Bolivia, CONAIE in Ecuador has been negatively affected by entering the realm of electoral politics. The difficulties presented by entering electoral politics can be seen through CONAIE's relationship with the Correa regime. After eventually supporting Correa in his first election, Pachakutik, the political party of CONAIE, was given several government positions. In these positions Pachakutik and CONAIE were unable to make changes they desired, but instead lost support from those who now saw the movement as selling out.

In 2009, CONAIE and Pachakutik completely boycotted presidential elections, which perhaps helped them regain legitimacy. CONAIE now must struggle against paternalistic top-down neoextractive development policies. They have done this as a movement outside of the state, while Pachakutik still contests and does well in local elections. This new focus on small local elections rather than large presidential ones perhaps illustrates a new approach for movements to enter the state apparatus. While useful on a local level, it has severe limits for structural change due to centralization and concentration of power in the executive branch in most Latin American states. 
The Zapatistas are firmly placed as the second most successful, behind the MST, of the studied movements. Although facing constant state repression they have managed to live mostly autonomously. This alone is a huge victory. Examples of their success include two hospitals, eighteen clinics, 800 community health houses, and over 500 health promoters, as well as, three hundred schools, 1,000 educational promoters and a center for secondary education (Zibechi, 2012: p. 132). I suggest that the central problem of the Zapatista autonomy model is that they still must face negative state mechanisms such as repression, extractive development policies, cooptation, and so on, but they do not depend on the state as a defensive mechanism like the MST. It is possible to argue that the Zapatistas, instead of using the state as a defensive mechanism, draw on transnational social movements and NGOs as a defensive mechanism. This can be observed in transnational solidarity groups and transnational human rights groups. ${ }^{10} \mathrm{I}$, however, am seeking to examine simply movements and the state. The role of transnational networks in providing a defensive mechanism and/or spreading the ideas of social movements is certainly an issue to be examined. ${ }^{11}$

In our shifting globalizing world, movements must make difficult decisions regarding how to interact with the state. While more autonomous movements have displayed greater success, it is certainly not a guarantee of it. Movements like the MST and the Zapatistas provide a glimmer of hope from what is still the most unequal continent in the world, laboratory of neoliberalism and empires, that another world is possible. Through their innovative tactics and thought they challenge the way we see the world as well. For perhaps the first time in history, the ideas of the MST or Zapatistas can instantly reach the citizens of the industrialized north, allowing for the creation of an international "multitude" (Chabot and Duyvendak, 2002: p. 697-740 and Hardt and Negri, 2010). Although it is indeed tempting to only attribute to movements the immediate outcomes of their efforts, we must also not forget the long-term effects through diffusion, reframing issues, and undermining hegemonic ideologies. As Zhou Enlai said when asked what he thought of the French Revolution, "It is too early to say."

\footnotetext{
10 See also: Barmeyer, Developing Zapatista Autonomy. Brysk, Alison. Globalization and human rights. Berkeley: University of California Press, 2002. Oleson, International Zapatismo.

11 (See the discussion of "transnational advocacy networks" in Keck and Sikkink 1998, and "transnational social movements, networks and norms" in Khagram et al. 2002)
} 


\section{Bibliography}

Acosta, Alberto. 2011. "Extractivism and Neoextractivism: Two Sides of the Same Curse." In Beyond Development: Alternative Visions from Latin America, edited by M. Lang and D.Mokrani, 61-86. Amsterdam: Rosa Luxemburg Institute.

Barmeyer, Niels. 2009. Developing Zapatista Autonomy: Conflict and NGO Involvement in Rebel Chiapas. Albuquerque, NM: University of New Mexico Press.

Becker, Marc. 2008. Indians and leftists in the making of Ecuador's modern indigenous movements. Durham: Duke University Press.

Becker, Marc. 2012. "Social Movements and the Government of Rafael Correa: Confrontation or Cooperation?" In Social Movements and Leftist Governments in Latin America: Confrontation or Cooptation?, edited by Gary Prevost, Carlos Oliva Campos, and Harry E. Vanden, 116-136. London: Zed Books.

Becker, Marc. 2013. "Ecuador: Indigenous Struggles and the Ambiguities of Electoral Power." In The New Latin American Left: Cracks in the Empire, edited by Jeffery R. Webber and Barry Carr, 213-232. Lanham, MA: Rowman and Littlefield Publishers, Inc.

Becker, Marc. 2013. "The Stormy Between Rafael Correa and Social Movements in Ecuador." Latin American Perspectives 40, May (2013): 43-62.

Brysk, Alison. 2002. Globalization and human rights. Berkeley: University of California Press.

Casanova, Pablo González. 2005. "The Zapatista 'Caracoles': Networks of Resistance and Autonomy." Socialism and Democracy 19, November (2005): 79-92.

Chabot, Sean and Jan Willem Duyvendak. 2002. "Globalization and Transnational Diffusion Between Social Movements: Reconceptualizing the Dissemination of the Gandhian Repertoire and the 'Coming Out' Routine." Theory and Society 31, May (2002): 697-740.

Ciccariello-Maher, George. 2013. "Constituent Moments, Constitutional Processes: Social Movements and the New Latin American Left." Latin American Perspectives 40, May (2013): 126145.

Collier, David and James Mahoney. 1996. "Research Note: Insights and Pitfalls: Selection Bias in Qualitative Research.” World Politics 49, no. 1 (1996): 56-91.

Dangl, Benjamin. 2010. Dancing with Dynamite: Social Movements and States in Latin America. Edinburgh: AK Press.

Della Porta, Donatella. 2002. "Comparative Politics and Social Movements." In Methods of Social Movement Research, edited by Bert Klandermans and Suzanne Staggenborg, 286-313. Minneapolis, MN: University of Minnesota Press.

EZLN. First Declaration of the Lacandón Jungle. Jan, 1994.

EZLN. Second Declaration of the Lacandón Jungle. June, 1994. 
EZLN. Fourth Declaration of the Lacandón Jungle. Jan, 1996.

EZLN. Fifth Declaration of the Lacandón Jungle. July, 1998.

EZLN. Sixth Declaration of the Lacandón Jungle. July, 2005.

Fuentes, Federico. 2010. "Government, Social Movements, and Revolution in Bolivia Today." International Socialist Review. 76, March (2010).

Gamson, William A. 2003. "Defining Movement 'Success."' In The Social Movements Reader: Cases and Concepts, edited by Jeff Godwin and James M. Jasper. Malden, 350-352. MA: Blackwell Publishing.

Giugni, Marco. 1999. "How Social Movements Matter: Past Research, Present Problems, Future Developments." In How Social Movements Matter, edited by Marco Giugni, Doug McAdam and Charles Tilly, xiii-xxxiii. Minneapolis: University of Minnesota Press.

González Casanova, Pablo. 2005. "The Zapatista Caracoles: Networks of Resistance and Autonomy." Socialism and Democracy. 19, 3(2005): 79-92.

Hardt, Michael, and Antonio Negri. 2000. Empire. Cambridge, Mass.: Harvard University Press.

Harvey, Neil. 2005. "Inclusion through Autonomy: Zapatistas and Dissent." NACLA Report on the Americas September-October (2005): 12-16.

Hellman, Judith A. 1992. "The Study of New Social Movements in Latin America and the Question of Autonomy." In New Social Movements in Latin America: Identity, Strategy and Democracy, edited by Arturo Escobar and Sonia E. Alvarez. Boulder, 52-61. CO: Westview Press.

Keck, Margaret E., and Kathryn Sikkink. 1998. Activists beyond borders: advocacy networks in international politics. Ithaca, N.Y.: Cornell University Press.

Khagram, Sanjeev. 2002. Restructuring world politics: transnational social movements, networks, and norms. Minneapolis: University of Minnesota Press.

Mora, Mariana. 2007. “Zapatista Anticapitalist Policies and the 'Other Campaign': Learning from the Struggle for Indigenous Rights and Autonomy. Latin American Perspectives 34, March (2007): 64-77.

Morales, Waltraud Q. 2012. "Social Movements and Revolutionary Change in Bolivia." In Social Movements and Leftist Governments in Latin America: Confrontation or Co-optation?, edited by Gary Prevost, Carlos Oliva Campos, and Harry E. Vanden, 49-87. London: Zed Books.

Motta, Sara C. 2013. "Reinventing the Lefts in Latin America: Critical Perspectives from Below." Latin American Perspectives 191, July (2013): 5-18.

Oikonomakis, Leonidas. 2014. "Cocaleros on Morales: 'What a Monster We Created." Roar Magazine. March 11, 2014. 
Olesen, Thomas. 2005. International Zapatismo: The Construction of Solidarity in the Age of Globalization. London: Zed.

Reyes, Alvaro. 2012. "Revolutions in the Revolutions: A Post Counter-Hegemonic Moment for Latin America?" The South Atlantic Quarterly 111, Winter (2012): 1-27.

Rimisp - Latin American Center for Rural Development. 2011. Poverty and Inequality Latin American Report 2011. Santiago, Chile.

Robinson, William I. 2008. Latin America and Global Capitalism a Critical Globalization Perspective. Baltimore: Johns Hopkins University Press.

Slater, David. 1994. "Power and Social Movements in the Other Occident: Latin American in an International Context." Latin American Perspectives 21, no. 2 (1994): 11-37.

Stahler-Sholk, Richard. 2007. "Resisting Neoliberal Homogenization: The Zapatista Autonomy Movement." Latin American Perspectives 34, March (2007): 48-63.

Stahler-Sholk, Richard. 2010. "The Zapatista Social Movement: Innovation and Sustainability." Alternatives: Global, Local, Political 35, July-September (2010): 269-290.

Tarrow, Sidney G. 1994. Power in Movement: Social Movements, Collective Action, and Politics. Cambridge [England]: Cambridge University Press.

Tilly, Charles. 1999. "From Interactions to Outcomes in Social Movements." In How Social Movements Matter, edited by Marco Giugni, Doug McAdam and Charles Tilly, 253-270. Minneapolis: University of Minnesota Press.

Van Cott, Donna Lee. 2005. From Movements to Parties in Latin America: the Evolution of Ethnic Politics. Cambridge: Cambridge University Press.

Vanden, Harry E. 2007. "Social Movements, Hegemony, and New Forms of Resistance." Latin American Perspectives, 34, no. 2 (2007): 39-55.

Vanden, Harry E. 2012. “The Landless Rural Worker's Movement and their waning influence on Brazil's Workers' Party Government." In Social Movements and Leftist Governments in Latin America: Confrontation or Co-optation?, edited by Gary Prevost, Carlos Oliva Campos, and Harry E. Vanden, 34-48. London: Zed Books.

Vergara-Camus, Leandro. 2009. "The Politics of the MST: Autonomous Rural Communities, the State, and Electoral Politics.” Latin American Perspectives, 36 no. 4 (2009): 178-191.

Vergara-Camus, Leandro. 2013. "Revolution in Times of Neoliberal Hegemony: The Political Strategy of the MST in Brazil and the EZLN in Mexico." In The New Latin American Left: Cracks in the Empire, edited by Jeffery R. Webber and Barry Carr, 95-115. Lanham, MA: Rowman and Littlefield Publishers, Inc.

Vlana, Nilton. 2013. "Brazil's Left Parties are Old and Bureaucratized, Warns MST’s Leader.“ Braz:il, July, 2013. 
Webber, Jeffery R. 2010. "From Rebellion to Reform: Image and Reality in the Bolivia of Evo Morales.” International Socialist Review. 73, September (2010).

Webber, Jeffery R. 2013. "From Left-Indigenous Insurrection to Reconstituted Neoliberalism in Bolivia: Political Economy, Indigenous Liberation, and Class Struggle, 2000-2011.” In The New Latin American Left: Cracks in the Empire, edited by Jeffery R. Webber and Barry Carr, 149-190. Lanham, MA: Rowman and Littlefield Publishers, Inc.

Webber, Jeffery R. and Barry Carr. 2013. The New Latin American Left: Cracks in the Empire. Lanham, MD: Rowman \& Littlefield Publishers, Inc.

Williamson, John. 1989. "What Washington Means by Policy Reform." In Latin American Readjustment: How Much Has Happened, edited by John Williamson. Washington DC: Institute for International Economics.

Wright, Angus Lindsay, and Wendy Wolford. 2003. To Inherit the Earth: the Landless Movement and the Struggle for a New Brazil. Oakland, CA.: Food First Books.

Zibechi, Raúl. 2005. "Subterranean Echos: Resistance and Politics “desde el Sótano.” Socialism and Democracy 19 no. 3 (2005): 13-39.

Zibechi, Raúl. 2012. Territories in Resistance: A Cartography of Latin American Social Movements. Oakland, CA: AK Press. 


\section{Appendix}

\begin{tabular}{|c|c|c|c|c|}
\hline Movement & $\begin{array}{l}\text { Degree of } \\
\text { Autonomy }\end{array}$ & Stated Goals & Outcomes & $\begin{array}{l}\text { Degree of } \\
\text { Success }\end{array}$ \\
\hline $\begin{array}{l}\text { Movimiento al } \\
\text { Socialismo (MAS) } \\
\text { Bolivia }\end{array}$ & $\begin{array}{l}\text { Complete } \\
\text { integration }\end{array}$ & $\begin{array}{l}\text { Communitarian socialism } \\
\text { Nationalization } \\
\text { hydrocarbons } \\
\text { Redrafting of constitution } \\
\text { Indigenous liberation } \\
\text { Referendum on autonomy }\end{array}$ & $\begin{array}{l}\text { "Andean- } \\
\text { Amazonian } \\
\text { Capitalism" } \\
\text { New constitution } \\
\text { Partial } \\
\text { nationalization }\end{array}$ & Low \\
\hline $\begin{array}{l}\text { Confederación de } \\
\text { Nacionalidades } \\
\text { Indígenas del } \\
\text { Ecuador } \\
\text { (CONAIE) } \\
\text { Ecuador }\end{array}$ & $\begin{array}{l}\text { Partial } \\
\text { integration }\end{array}$ & $\begin{array}{l}\text { Land/agrarian reform } \\
\text { Economic development } \\
\text { Bilingual education } \\
\text { Recognition of indigenous } \\
\text { nationalities } \\
\text { Plurinational constitution }\end{array}$ & $\begin{array}{l}\text { Little success with } \\
\text { land/agrarian } \\
\text { reform } \\
\text { Continued neo- } \\
\text { extractivism } \\
\text { New constitution }\end{array}$ & Medium \\
\hline $\begin{array}{l}\text { Movimento dos } \\
\text { Trabalhadores } \\
\text { Rurais Sem Terra } \\
\text { (MST) } \\
\text { Brazil }\end{array}$ & $\begin{array}{l}\text { Separate } \\
\text { interaction }\end{array}$ & $\begin{array}{l}\text { Land reform } \\
\text { Autonomous schools and } \\
\text { healthcare } \\
\text { Struggle against GMOs and } \\
\text { Agribusiness }\end{array}$ & $\begin{array}{l}35 \text { million acres } \\
\text { expropriated, used } \\
\text { by } 400,000 \text { families } \\
1,800 \quad \text { schools } \\
\text { with160,000 } \\
\text { students }\end{array}$ & High \\
\hline $\begin{array}{ll}\text { Ejército } & \text { Zapatista } \\
\text { de } & \text { Liberación } \\
\text { Nacional } & \text { (EZLN) } \\
\text { Mexico } & \end{array}$ & Autonomy & $\begin{array}{l}\text { Housing } \\
\text { Land reform } \\
\text { Employment } \\
\text { Independence (autonomy) }\end{array}$ & 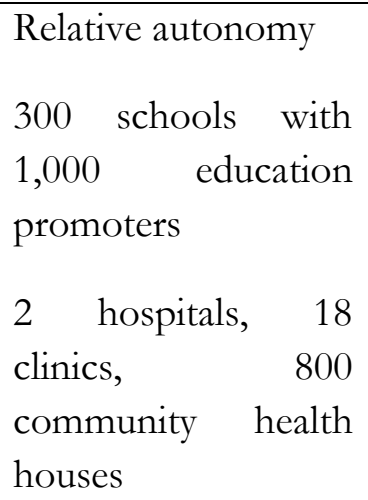 & High \\
\hline
\end{tabular}

Table 1: Movement Outcomes vis-à-vis Stated Goals (Source: Author) 